\title{
Toward endoscopic ultrafast laser microsurgery of vocal folds
}

\author{
Adela Ben-Yakar, Christopher Hoy, W Neil Everett, James Kobler ${ }^{*}$ \\ From 2nd Scientific Meeting of the Head and Neck Optical Diagnostics Society \\ San Francisco, CA, USA. 23-24 January 2010
}

Vocal fold scarring can arise from disease or postsurgical wound healing and is one of the predominant causes of voice disorders. Focused ultrafast laser pulses have been previously demonstrated to create tightly confined sub-surface ablation in a variety of tissue, including vocal folds. Here, we demonstrate how we can take advantage of this unique ability of ultrafast laser ablation to create sub-surface vocal fold microsurgeries with a goal for eventually creating a plane in tough sub-epithelial scar tissue into which biomaterials can be injected. Specifically, we create sub-epithelial ablations in vocal fold tissue in under 1 minute using sub- $\mu \mathrm{J}$ pulses from a compact, commercially available amplified ultrafast laser system from Raydiance Inc., operating at a $500 \mathrm{kHz}$ repetition rate. The use of relatively high repetition rates, with a small number of overlapping pulses, is critical to achieving ablation in reasonable amounts of time while still avoiding significant heat deposition. Additionally, we use multiphoton fluorescence of the ablation region and SHG imaging of collagen fibers to obtain visual feedback of tissue structure and confirm successful ablation. Lastly, we demonstrate microsurgery using amplified ultrafast laser pulses delivered through over 1 meter of air-core photonic crystal fiber to a laser scanning microsurgery probe, illustrating the feasibility of developing an ultrafast laser surgical laryngoscope. We aim to further develop this clinical tool through demonstration of laryngeal microsurgery using a compact laser system in conjunction with a larynx-specific fiber-based surgery probe.
Published: 29 October 2010

doi:10.1186/1758-3284-2-S1-029

Cite this article as: Ben-Yakar et al:: Toward endoscopic ultrafast laser microsurgery of vocal folds. Head \& Neck Oncology 2010 2(Suppl 1):O29.
Centre for Laryngeal Surgery and Voice Rehabilitation, Massachusetts General Hospital, Boston, USA
Submit your next manuscript to BioMed Central and take full advantage of:

- Convenient online submission

- Thorough peer review

- No space constraints or color figure charges

- Immediate publication on acceptance

- Inclusion in PubMed, CAS, Scopus and Google Scholar

- Research which is freely available for redistribution

Submit your manuscript at www.biomedcentral.com/submit
C Biomed Central 